УДК [37:503]:373:[-043.84:316.3](4-13)

DOI:

Марія Чепіль, доктор педагогічних наук, професор, завідувач кафедри загальної педагогіки та дошкільної освіти Дрогобииького державного педагогічного університету імені Івана Франка

\title{
ОСОБЛИВОСТІ РЕАЛІЗАЦІЇ ЕКОЛОГІЧНОЇ ОСВІТИ У ПОЧАТКОВИХ ТА СЕРЕДНІХ ШКОЛАХ ПІВДЕННОЇ СВРОПИ
}

У статті проаналізовано особливості реалізачії екологічної освіти в початкових та середніх школах Південної Свропи та з'ясовано перспективи подальших наукових розвідок у даному напрямі засобами екологічної освіти. Виявлено різноманітність способів, якими країни Південної Європи звертаються до екологічної освіти в системах початкової та середньої школи. 3 'ясовано, щчо екологічна освіта є обов 'язковою областю навчальної програми в початковій та молодшій середній освіті із застосуванням різних підходів, а в ряді випадків у поєднанні з іншими підходами тощо.

Ключові слова: екологічна освіта; курикулум; початкова школа; середня школа; Південна Європа.

Jim. 6.

Mariya Chepil, Doctor of Sciences (Pedagogy), Professor, Head of the General Pedagogy and Preschool Education Department, Drohobych Ivan Franko State Pedagogical University

\section{FEATURES OF REALIZATION OF ECOLOGICAL EDUCATION IN ELEMENTARY AND SECONDARY SCHOOLS OF SOUTHERN EUROPE}

The author of the article analyzes the peculiarities of the implementation of environmental education into primary and secondary schools in Southern Europe and the prospects for further research in this direction by means of environmental education. A variety of ways in which the countries of Southern Europe are turning to environmental education in primary and secondary school systems has been revealed. It was found that environmental education is a mandatory area of the curriculum in primary and lower secondary education using different approaches, and in some cases in combination with other approaches.

Environmental education is one of many spheres (others include health education and consumer education) that are considered as cross-cutting themes and should be included in teaching at all levels. Other countries that refer to environmental education for their common goals are Austria, Belgium, Greece, Ireland, Luxembourg, Sweden and the United Kingdom (Scotland).

In some countries advanced or specialized environmental education is available. The content varies according to the type of course. The most advanced courses are offered individual specialized courses: a) principles of environmental sciences (Greece); b) ecological and consumer education (Portugal); c) earth Sciences and the Environment (Spain).

Prospects for further research in this direction may be to ensure adequate initial training and advanced training of teachers, to ensure that teachers are well equipped to provide environmental education in various fields of curriculum.

Keywords: environmental education; a curriculum; an elementary school; a secondary school; Southern Europe.

П остановка проблеми. Процес екологізації освіти за кордоном почався значно раніше, ніж в Україні. В країнах Західної Європи та США відбувається зміщення акцентів природоохоронної діяльності 3 контролю за станом природного середовища до запобігання іiі забруднення. Спостерігається широке включення питань навколишнього середовища в усі сфери внутрішньої і зовнішньої політики, загострюється увага на тому, що господарська діяльність людини в навколишньому середовищі повинна строго відповідати принципам сталого розвитку $[4,66]$. Екологічна освіта була передумовою виникнення освіти для сталого розвитку та стала іiі базою. Зараз освіта для сталого розвитку охопила всі сфери діяльності людини і уособлює значно ширше поняття, ніж екологічна освіта $[5,56]$.

Аналіз останніх досліджень та публікацій. Підгрунтя екологічного виховання та освіти формувалися під впливом гуманістичних ідей відомих мислителів різних епох: Я. Коменського, Й. Песталоцці, Ж. Руссо та інших, а також відображені в наукових працях, освітній теорії та практиці вітчизняних учених та педагогівпрактиків: В. Вернадського, Г. Сковороди, К. Ушинського, В. Сухомлинського, С. Русової та інших. Питання екологічного виховання й освіти 
відображені також у компаративних дослідженнях вітчизняних учених: В. Ломакович та І. Рудковської (Німеччина), Н. Микитенко (Канада), С. Старовойт, Я. Полякової, Г. Марченко, Т. Кучай (Велика Британія), С. Романової, О. Романовського, Ю. Чернецького, М. Швед (США) та інших [1, $150]$.

Однак, глобальний характер проблем зумовлює потребу спільного пошуку країнами шляхів їх розв'язання, тому порівняльні дослідження набувають особливої значущості. Важливість наукового забезпечення модернізаційних процесів у вітчизняній освіті з позиції відповідності сучасним світовим трансформаціям підкреслено у стратегічних документах, що визначають напрями iї розвитку в Україні. Так, у Національній доктрині розвитку освіти (2002 р.) серед пріоритетних напрямів державної освітньої політики визначено інтеграцію вітчизняної освіти до європейського та світового освітнього просторів, що передбачає масштабні порівняльні розвідки [3, $7-8]$. Нині існує два підходи до врахування екологічної освіти в процесі впровадження освіти для сталого розвитку: а) трансформування екологічної освіти в освіту для сталого розвитку, її поширення на досі не властиві галузі. Головними впроваджувальними інституціями $є$ спільні установи екологічного та освітнього спрямування; б) створення нової структури на державному рівні, яка безпосередньо виконує функції з освіти для сталого розвитку. В цьому випадку спостерігається паралельне існування екологічної освіти й освіти для сталого розвитку 3 обов'язковою координацією їх дій $[5,56]$. Як зазначає Л. Загородня, в країнах ЄС чітко простежується наступність у змісті екологічних навчальних програм, принципах, підходах, формах, методах екологічної освіти дошкільників і молодших школярів [2, 4].

Мета статті - проаналізувати особливості реалізації екологічної освіти в початкових та середніх школах Південної Свропи та з'ясувати перспективи подальших наукових розвідок.

Виклад основного матеріалу. Екологічна політика ЄС розвивалася впродовж останніх двох десятиліть, а екологічна освіта - як частина іiі ефективної реалізації. У тандемі, концепт “середовища" змінювався з часом. Ранні погляди зосереджувалися на зміні екосистем та впливі різних форм забруднення. Однак соціальні, економічні та культурні аспекти навколишнього середовища почали все більше усвідомлюватися, тому включення сталого розвитку робить це поняття ще більш широким. Роль освіти в екологічній політиці була чітко визначена в Резолюції, прийнятій Радою міністрів у 1988 році, в якій стверджувалося, що метою екологічної освіти є підвищення громадської обізнаності про проблеми в цій галузі, а також закладання основи для повної інформованої й активної участі особистості в охороні навколишнього середовища та обережному і раціональному використанні природних ресурсів.

У 1993 році Європейський Парламент закріпив цей підхід у Резолюції, яка закликала державичлени та Комісію “включати екологічний аспект у всі аспекти освіти на всіх рівнях" й “підкреслювати фундаментальну роль шкіл та їхніх вчителів розробці та реалізації політики”. Крім того, П’ята екологічна програма Свропейського Співтовариства спрямована на те, щоб інтегрувати екологічний аспект у всі основні сфери політики як ключовий чинник для забезпечення поведінкових змін, необхідних для сталого розвитку. У цьому контексті інформація та освіта стали важливими компонентами, що доповнюють законодавство та ринкові інструменти, спрямовані на зміну екологічно шкідливої поведінки та перехід до сталого розвитку [6, $4-5]$.

Як зазначалося групою учених (West et al., 1999), керівні принципи навчальних програм змінюються з точки зору того, якою мірою вони призначають те, що має охоплюватися. Можна розрізнити дві моделі. Більше половини країн надають детальні рекомендації / програми навчального плану (наприклад, Австрія, Бельгія (Фламандські та Французькі громади), Франція, Німеччина (Баварія, Північний Рейн-Вестфалія і Тюрінгія), Греція, Ірландія, Люксембург, Португалія та Великобританія (Англія). У деяких 3 цих країн навчальний план $є$ більш прописаним, ніж в інших, але менші детальні характеристики змісту навчальних програм зазвичай наводяться в Данії, Фінляндії, Італії, Нідерландах, Іспанії та Швеції. Важливо відзначити, що, на відміну від багатьох інших областей навчальної програми, екологічна освіта не обов'язково викладається як окремий предмет. Одним з наслідків цього, а також того факту, що документи з навчальних планів не обов'язково прописують зміст, $є$ те, що в деяких країнах існує гнучкість щодо ступеня охоплення екологічної освіти. Як зазначив один з чиновників Міністерства: “ступінь викладання залежить від особистості вчителя”. "Навіть там, де існує політика місцевих органів влади, надання послуг у школах залишається нерівним і значною мірою залежить від інтересів та волі невеликої кількості відданих вчителів" $[6,6]$.

Глобальні цілі та цінності екологічної 


\section{ОСОБЛИВОСТІ РЕАЛІЗАЦІЇ ЕКОЛОГІЧНОЇ ОСВІТИ УПОЧАТКОВИХ ТАСЕРЕДНІХ ШКОЛАХПІВДЕННОӤ ЄВРОПИ}

освіти в початкових школах. На початковому рівні більшість держав-членів включають екологічну освіту до загальної постановки цілей та / або цінностей. До таких країн належать: Австрія, Бельгія (Фламандська та Французька громади), Данія, Фінляндія, Німеччина (Баварія і Тюрінгія), Греція, Ірландія, Люксембург, Іспанія, Швеція, Великобританія (Англія, Уельс, Північна Ірландія та Шотландія). У навчальних документах Данії, Фінляндії, Німеччини, Iсnанії, Швеції та Великобританії(Англія) особлива увага приділяється елементу навколишнього середовища. Ми розглядаємо загальні цілі та ціннісні висловлювання цих країн, а екологічна освіта була розглянута відносно високо, і тому досягла відносно високого рівня в початковій освіті [6, 6-7].

Розглянемо детальніше особливості реалізації екологічної освіти в загальноосвітніх школах країн Південної Європи. Зокрема, історія екологічної освіти в Греції налічує більше 30 років. За цей час в Греції було проведено близько 50 загальнонаціональних семінарів 3 питань навколишнього середовища, підготовлено кілька об’ємних посібників з цієї надзвичайно актуальної проблеми. Велика частина державних документів націлена на те, щоб розкрити двері школи для широкої суспільності, збагатити цінності сучасних школярів, активізувати зв'язки та взаємодії 3 соціальним і природним оточенням. Закони від 31 липня 1990 року і 3 квітня 1991 регламентують включення питань навколишнього середовища в навчальні програми 3 усіх основних шкільних предметів.

Екологічна освіта в Греції має відповідати слідуючим вимогам: забезпечувати розуміння не тільки факту реального існування екологічних проблем, а й усвідомлення того, що вони $\epsilon$ результатом взаємодії багатьох фінансових, соціальних, політичних та економічних причин, причому як в міських, так і в сільських районах; давати кожному учневі можливість придбати знання, відчуття цінності природи, відносини, активний інтерес, а також розуміння та навички, необхідні для захисту і оптимізації місцевого навколишнього середовища; мотивувати окремих громадян, соціальні групи і суспільство в цілому засвоїти нові моделі поведінки, що дозволяють краще керувати навколишнім середовищем [4, 68].

Натомість в Іспанії, виокремлено щонайменше три загальні цілі навчання для учнів початкової школи, які мають зв'язок з екологічною освітою: 1) співпрацювати у плануванні та здійсненні групової діяльності, приймати демократично встановлені норми та правила, формулювати [свої] цілі та інтереси з інтересами інших членів групи, поважати чіткі точки зору і брати на себе відповідальність за такі погляди;

2) осмислювати і встановлювати зв'язки між фактами і явищами природного і соціального середовища, активно сприяти можливому захисту, збереженню і поліпшенню навколишнього середовища;

3) знати про культурну спадщину, брати участь у їі збереженні та вдосконаленні, поважати культурну та мовну різноманітність - як право обох груп, так і окремих осіб - для того, щоб сприяти формуванню інтересу та поваги у відношенні до здійснення цього права.

Екологічна освіта $є$ однією з багатьох сфер (інші включають медичну освіту (health education) та освіту споживачів), які розглядаються як наскрізні теми і які повинні бути включені до викладання на всіх рівнях. Іншими країнами, які посилаються на екологічну освіту в своїх загальних цілях є Австрія, Бельгія, Греція, Ірландія, Люксембург, Швеція та Великобританія (Шотландія).

Екологічна освіта - вища загальна середня освіта (upper secondary general education). На вищому рівні середньої освіти зростає спеціалізація навчальних програм. Незважаючи на те, що деякі предмети можуть залишатися обов'язковими для частини, або всієї фази вищої середньої школи, курикулум ділиться на галузі, орієнтації, напрямки або програми спеціалізації у всіх країнах [6].

Як відзначає, Е. Стокс на цьому рівні деякі предмети $є$ обов'язковими в більшості країн $\mathrm{CC}$ [6]. Країни можуть бути диференційовані з точки зору предметів, які учні вивчають у вищій / післяобов' язковій середній загальній освіті. Існує велика різниця в кількості предметів. У той час як у Великобританії (Англія, Уельс та Північна Ірландія) учні загалом вивчають невелику кількість предметів - близько чотирьох або п'яти на першому році вищої середньої освіти, у всіх інших країнах ця кількість становить від п'яти до десяти (наприклад, Німеччина, Данія, Франція, Греція, Ірландія, Люксембург, Іспанія, Великобританія (Шотландія)). У деяких країнах вона перевищує десять предметів (наприклад, Австрія). Існує також відмінність щодо предметів, які $\epsilon$ обов'язковими. Немає обов'язкових предметів, які учні повинні вивчати у Великобританії, і лише один предмет - в Ірландії (ірландська). У всіх країнах, окрім Ірландії, Португалї, Іспанї та Великобританії, деякі природничі науки є обов'язковими. Це важливо, оскільки екологічна освіта часто розглядається через природничі предмети. 


\section{ОСОБЛИВОСТІ РЕАЛІЗАЦЇ̈ ЕКОЛОГІЧНОЇ ОСВІТИ У ПОЧАТКОВИХ ТАСЕРЕДНІХ ШКОЛАХ ПІВДЕННОЇ ЄВРОПИ}

Спеціалізовані варіанти екологічної освіти (вища середня). У ряді країн доступні просунуті або спеціалізовані варіанти екологічної освіти. Зміст змінюється залежно від типу курсу. Пропонуються найбільш просунуті курси, тобто окремі спеціалізовані курси: а) Принципи екологічних наук (Греція); б) Екологічна та споживацька освіта (Португалія); в) Науки про Землю та навколишнє середовище (Іспанія).

Наукові засади та аналіз екологічних явищ. У галузі наукових принципів та аналізу екологічних явищ були включені наступні приклади: екологічна наука як сфера міждисциплінарного вивчення та дослідження, базові принципи екологічної науки (Греція); причини природного ризику та заходи щодо їх запобігання або коригування, дослідження екологічних проблем, використання наукових, соціологічних та історичних методів, збір / аналіз даних з різних джерел, науковий метод, системна теорія навколишнього середовища; зміни навколишнього середовища, наземні системи, геосфера, енергетичні баланси, атмосферний та гідросферичний баланс і регулювання, ризики та вплив на навколишнє середовище (Іспанія) [6, 17 $-18]$.

Соціально-економічні фактори, детермінанти або показники екологічних проблем. У сфері соціально-економічних факторів приклади змісту курикулуму включали: навколишнє середовище та якість життя, технологічний розвиток, моделі виробництва та споживання й сталий розвиток (Греція); концепт розвитку у поєднанні з соціальноекономічними перетвореннями, економічним розвитком та наслідками для навколишнього середовища, відсутність ресурсів як межі економічного розвитку - споживчих моделей розвинених країн, використання та заміни невідновлюваних ресурсів, сталого розвитку (Португалія); екологічні проблеми та їхні політичні, економічні та соціальні наслідки, екологічне здоров'я та якість життя, модель охорони природи та сталого розвитку, екологічні проблеми майбутнього (Іспанія).

Екологія та екосистеми. Приклади змісту, що стосуються екології та екосистем, включали наступні: базові екологічні поняття; організація та функціонування екосистеми; характеристики екосистем; зниження / відновлення екосистем, Середземноморські екосистеми, Грецькі екосистеми, екологія та людство (Греція); екологічна ефективність та саморегулювання екосистеми; потенційне використання та крихкість навколишнього середовища (Іспанія) [6, 19].

Греція. Указ Президента від 1988 року роз'яснив роль Міністерства охорони навколишнього природного середовища в екологічній освіті (the Ministry of the Environment in environmental education) і продемонстрував, що Міністерство несе відповідальність за надання фінансової підтримки для заходів, які сприяють екологічній освіті. У 1989 році Міністерство освіти (Міністерство освіти Греції, 1989) розповсюдило брошуру “Школа та довкілля” з інформацією про екологічну освіту. 31991 року екологічна освіта була визнана частиною початкової та середньої школи на національному рівні. Для сприяння екологічній освіті та впровадженню програм, що фінансуються Міністерством освіти у співпраці 3 іншими установами, було створено національний центр. На регіональному рівні по всій Греції були відкриті центри екологічної освіти 3 “відповідальним працівником” у кожному регіоні, відповідальним за екологічні освітні програми (Gravanis, 1992).

Італія. Документація, надана Міністерством охорони навколишнього середовища (the Ministry of the Environment, 2000), описує ANDREA, Національний архів екологічних досліджень та освіти (the National Archive of Environmental Research and Education), який $є$ базою даних Національної системи інформації, навчання та освіти з питань довкілля. (the National System for Information, Training and Education on Environmental Issues, INFEA), Остання є службою Міністерства охорони навколишнього природного середовища, яка об'єднує в мережу всіх партнерів Міністерства, що беруть участь у проектах екологічної освіти; вони варіюються від місцевих органів влади до неприбуткових організацій, університетів і дослідницьких центрів. Кожен Італійський регіон має низку державних i приватних агентств 3 екологічної освіти. Вони, як правило, пов'язані з регіональною адміністрацією i, через регіон, з національним Міністерством охорони навколишнього середовища. До центрів екологічної освіти входять “Територіальні лабораторії екологічної освіти”, які надають послуги, що пропонують інформацію та консультації для зацікавлених сторін. “Центри для досвіду” є “інформальними” школами для екологічного освіти; вони пропонують програми, які включають безпосередній досвід 3 навколишнім середовищем, часто використовуючи інноваційні методи навчання. “Центри регіональної координації” є більш новою ініціативою і випливають з бажання, висловленого регіональними адміністраціями щодо забезпечення більш послідовної інформаційної підготовки та освіти з питань довкілля [6, 24]. Також існує новий 


\section{ОСОБЛИВОСТІ РЕАЛІЗАЦІЇ ЕКОЛОГІЧНОЇ ОСВІТИ У ПОЧАТКОВИХ ТА СЕРЕДНІХ ШКОЛАХ ПІВДЕННОӤ ЄВРОПИ}

веб-сайт для екологічної освіти, який $\epsilon$ результатом співпраці між Регіональними інститутами досліджень, експериментів та реформування освіти (Regional Institutes of Research, Experimentation and Reforming Education, IRRSAE) та Міністерством народної освіти (the Ministry for Public Education). Це консультаційний центр, присвячений вчителям, які займаються екологічною освітою (Міністерство навколишнього середовища Італії, 2000) [6].

Португалія. Інститут освітніх інновацій (Тhe Institute for Educational Innovation) підтримує педагогічні інновації для впровадження екологічної освіти; як такий, він сприяв та заохочував проекти 3 екологічної освіти - зосереджуючи увагу на підготовці педагогічного персоналу, виробництві таких матеріалів, як “Маршрутний екологічний проект“ ('Itinerary Environmental Project'). Загалом, інновації впроваджувалися через спеціалізовані людські ресурси та схеми стимулювання. Мотив навколишнього середовища інтегрований у “Систему стимулювання якості освіти” з наступними завданнями: розробка проектів освітніх інновацій у школах; розробка наукових або проектів “дослідження в дії” у сфері освіти; організація обміну діяльністю - між школами, інноваційними або дослідницькими проектами (включаючи конференції, зустрічі тощо); публікація матеріалів, що стосуються інноваційних проектів та досліджень $[6,25]$.

Екологічна проектна робота. Способи покращення екологічної освіти реалізуються за допомогою таких заходів, як робота на місцях або спеціальні проекти. Такі проекти часто пов'язані 3 центрами, що фінансуються урядом, які надають екологічну освіту та ресурси. Нижче наведемо приклади 3 окремих країн Південної Європи.

Італія. Лабораторія регіональної екологічної освіти Фріулі-Венеція-Джулія (The Laboratorio Regionale di Educazione Ambientale del Friuli Venezia Giulia, LaREA) організовує кампанію 3 екологічної освіти, так звані еко-школи. Ця кампанія була розпочата в 1998/1999 навчальному році і спочатку було задіяно дев'ять шкіл регіону Фріулі-Венеція-Джулія. До 1999/2000 рр. було задіяно 34 школи в різних регіонах Італії. Метою кампанії є сприяння екологічній освіті в школах шляхом виготовлення матеріалів для викладання предмету (Міністерство навколишнього середовища Італії, 2000) [6, 25-26].

Іспанія. Наведемо приклади проектної роботи молодих учнів у наступних автономних регіонах:

1. У Андалусії, в рамках Програми екологічної освіти "VILLAGE" (за підтримки Ради $з$ питань науки і освіти та Ради 3 навколишнього середовища (the Science and Education Council and the Environment Council)) було забезпечено низку можливостей і кампаній для участі шкіл, таких як щорічна конкуренція - зробіть свою класну кімнату “зеленою”, “виростити свою власну деревну кампанію”, для якої дерева та саджанці поставляються до шкіл-учасниць, “кампанія турботи про наше узбережжя”, яка передбачає спостереження та збір даних 3 окремих прибережних районів та кампанія з еко-аудиту (школи-учасники можуть виграти еко-нагороду)

2. На Канарських островах відбулася низка заходів, пов'язаних 3 екологічною освітою, включаючи “Зберегти наші яри”, який був проектом 3 вивчення та спостереження, що базувався на семінарах та практичних заходах, таких як збір та сортування мотлоху та сміття.

3. У Ріоха, проект Центрів сталої освіти (the Sustainable Education Centres Project), спільне підприємство Ради 3 питань туризму та навколишнього середовища (the Tourism and Environmental Council) та Ради 3 питань освіти, культури, молоді та спорту (the Education, Culture, Youth and Sports Council) надають підтримку таким шкільним заходам, як “тіньовий театр ляльок”, щорічний захід, залучає учнів у дитячих дошкільних закладах та початкових школах до проведення лялькового спектаклю про відходи та утилізацію (Міністерство освіти і культури Іспанії, 1999) $[6,27]$.

Висновки і перспективи подальших розвідок. Це дослідження виявило різноманітність способів, якими країни Південної Європи звертаються до екологічної освіти в системах початкової та середньої школи. 3'ясовано, що екологічна освіта є обов'язковою областю навчальної програми в початковій та молодшій середній освіті, з використанням цілої низки різних підходів, а в ряді випадків - у поєднанні з іншими підходами.

Перспективами подальших наукових розвідок у даному напрямі може стати забезпечення адекватної первинної підготовки та підвищення кваліфікації вчителів, щоб забезпечити, щоб вчителі були добре обладнані для забезпечення викладання екологічної освіти в різних областях курикулуму.

\section{ЛІТЕРАТУРА}

1. Войтович, А. (2016). Екологічне виховання учнів початкових класів в Україні та Європі: компаративний аспект. Молодь $i$ ринок. Дрогобич, 2016. № 2 (133). С. 149-154.

2. Загородня, Л. Наступність в екологічній 


\section{ОСОБЛИВОСТІ РЕАЛІЗАЦІЇ ЕКОЛОГІЧНОЇ ОСВІТИ У ПОЧАТКОВИХ ТА СЕРЕДНІХ ШКОЛАХ ПІВДЕННОЇ ЄВРОПИ}

освіті дошкільників і молодших школярів: європейський досвід. URL: http://conf.kubg.edu.ua/ index.php/courses/preschool/paper/viewFile/157/145 (дата звернення: 03.04.2019).

3. Локшина, О. Зміст шкільної освіти в країнах Європейського Союзу: теорія і практика (друга половина XX - початок XXI ст.). Київ, 2009. 404 с.

4. Писанка, К. Проблеми екологічної освіти та виховання в різних країнах світу. Молодий вчений, 4 (07), 2014. С. 65-71.

5. Сталий розвиток суспільства: роль освіти. Путівник / За ред. В. Підліснюк. Київ, 2005. URL:http://ekmair.ukma.edu.ua/bitstream/handle/ $123456789 / 142 / \mathrm{Stalyi} \% 20 \mathrm{rozvytok} \%$ 20suspilstva.pdf?sequence $=1$ (дата звернення: 15.04.2019).

6. Stokes E., Edge A., \& West A. Environmental education in the educational systems of the European Union: Synthesis Report. Commissioned by the Environment Directorate-General of the European Commission. - Centre for Educational Research London School of Economics and Political Science, 2001, 31 p. URL: http://www.medies.net/ uploaded files/ee in_eu.pdf (дата звернення: 18.04.2019).

\section{REFERENCES}

1. Voitovych, A. (2016). Ekolohichne vykhovannia uchniv pochatkovykh klasiv v Ukraini ta Yevropi: komparatyvnyi aspekt [Ecological education of elementary school pupils in Ukraine and Europe: a comparative aspect]. Youth \& market. Drogobych, Vol. 2 (133), pp. 149-154. [in Ukrainian].

2. Zahorodnia, L. Nastupnist v ekolohichnii osviti doshkilnykiv i molodshykh shkoliariv: yevropeiskyi dosvid [Continuity in the ecological education of preschoolers and junior pupils: European experience.]. Available at: http://conf.kubg.edu.ua/index.php/ courses/preschool/paper/viewFile/157/145 (Accessed 03 Apr. 2019) [in Ukrainian].

3. Lokshyna, O. (2009). Zmist shkilnoi osvity v krainakh Yevropeiskoho Soiuzu: teoriia i praktyka (druha polovyna XX - pochatok XXI st.) [Content of school education in the countries of the European Union: theory and practice (second half of the XX beginning of the XXI century)]. Kyiv, 404 p. [in Ukrainian].

4. Pysanka, K. (2014). Problemy ekolohichnoi osvity ta vykhovannia $\mathrm{v}$ riznykh krainakh svitu [Problems of environmental education and education in different countries of the world]. The Young Scientist, 4 (07), 65-71. [in Ukrainian].

5. Pidlisniuk, V. (Ed.) (2005). Stalyi rozvytok suspilstva: rol osvity. Putivnyk [Sustainable development of society: the role of education. Guidebook]. Kyiv. Available at: http:// ekmair.ukma.edu.ua/bitstream/handle/123456789/ 142/Stalyi\% 20rozvytok \%20suspilstva.pdf? sequence $=1$ (Accessed 15 Apr. 2019) [in Ukrainian].

6. Stokes, E., Edge, A., \& West, A. (2001). Environmental education in the educational systems of the European Union: Synthesis Report. Commissioned by the Environment DirectorateGeneral of the European Commission. - Centre for Educational Research London School of Economics and Political Science, 31 p. Available at: http:// www.medies.net/_uploaded_files/ee in_eu.pdf (Accessed 18 Apr. 2019) [in English].

Стаття надійшла до редакції 10.05.2019

\section{G5808}

"Кожне слово вихователя повинно нести в собі добро, справедливість і қрасу - в цьому суть наших повчань”.

Василь Сухоминсьжий

педагог, публіиист, писъменник

Учень запитав: “Чи можна все життя керуватися одним словом?”

Виитель відповів: "Ie слово взаємність. Не роби іншим того, чого не бажаєи собі".

Конфучиій

давньокитайський боілософ

"Теремоги вчать наӥвних, а поразки - мудрих; успіхи дають одинииі уроків, а невдачі - тисячі. Вчіться на уроқах переможених".

Dжефбб О'Лipi

американський письменник, лірик,

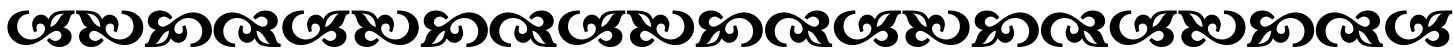

